\title{
WIKI IN AN UNIVERSITY COURSE: USE AND STUDENTS ATTITUDE
}

\section{Kornytska Yuliia ${ }^{1}$}

DOI: https://doi.org/10.30525/978-9934-571-89-3_17

The implemention of wikis in the training process and related studies have been on the increase in a recent decade. Wikis are considered as potentially effective teaching and learning tools since they facilitate the collaborative finding, creating and exchanging the information $[1 ; 2]$ and initiate autonomous collaborative learning process [3], that have a great importance in the modern educational paradigm. In university courses, wikis serve as a platform for the collaborative creation of curricular content and as an information hub [4].

However, not that many scientisits seem to consider relationships between using wikis and the student acceptance of this technology. At the same time, learning results are highly dependent on students' interest and attitude that are not always high and positive by default $[5 ; 6]$. Therefore, the aim of this research is to clarify whether students consider wikis as useful and rewarding elements in training process and determine how high the motivation to participate is.

To collect data we used an empirical investigation with a survey conducted online at the end of the experimental period (lasted two semesters - 36 weeks). The survey contained four blocks of questions and statements dealt with the evaluation of the wiki-based course components. The participants were offered to use a five point Likert scale with an alternative variant "I cannot evaluate". Obtained data was processed by means of the statistical analysis software. The participants were sixtyfour students attending the ESP course at the Management and Marketing Department at National Technical University of Ukraine "Igor Sikorsky Kyiv Polytechnic Institute".

Having analyzed the recent researches, practical experience and technical options, we turned to the wikis' potential for:

- creating the course information hub;

- establishing the course resource repository;

- building students' portfolio;

- setting up collaboration activities platform.

Below, we present the results of our experiment.

1. Course information hub. All course information-curriculum, evaluation criteria, rubrics, test schedule, assignments, handout materials, etc. -was organized in blocks and posted on the wiki page. It allowed permanent independent access, so, students were able to check in to get all necessary information at any time.

The average evaluation was in the range 4.8-5 (from 1 "not at all" to 5 "very" incrementally) for parameters "required", "useful", and "usable".

\footnotetext{
${ }^{1}$ National Technical University of Ukraine

"Igor Sikorsky Kyiv Polytechnic Institute", Ukraine
} 
2. Repository. Wiki was used to publish relevant course resources - texts, audio, and video. We also offered links to topical articles, news and podcasts. Extra block for students enabled them to create a collection of links where they posted, commented, grouped and classified relevant links.

The average evaluation was in the range 4.4-4.8 (from 1 "not at all" to 5 "very" incrementally) for parameters "required", "useful", and "usable".

3. Portfolio. The platform was used to place students' productions in a portfolio. Portfolio included written tasks, test results, video taken in a classroom, presentations etc. It offered good opportunity to monitor skills and knowledge development, determine training efficiency and identify areas that required improvement.

The average evaluation was in the range $4.2-4.6$ (from 1 "not at all" to 5 "very" incrementally) for parameters "required", "useful", and "usable".

4. Collaboration activities platform. Having ensured the coherence with the curriculum, we included a range of wiki-based activities into regular training process. At the end of the experiment, students evaluated wiki-based activities they participated in and compared them with traditional tasks. The response scale used for collecting data contains the range from 1 (very poor) to 5 (very good).

The average evaluation was in the range $4-4.6$ (between "good" and "very good") for parameters "interesting" $(4,8)$, "rewarding" $(4,5)$, "challenging" $(4,4)$ and "usable" $(4,3)$.

While compared with the regular in- and out-of- classroom tasks, wiki-based activities received relatively high ratings (Figure 1).

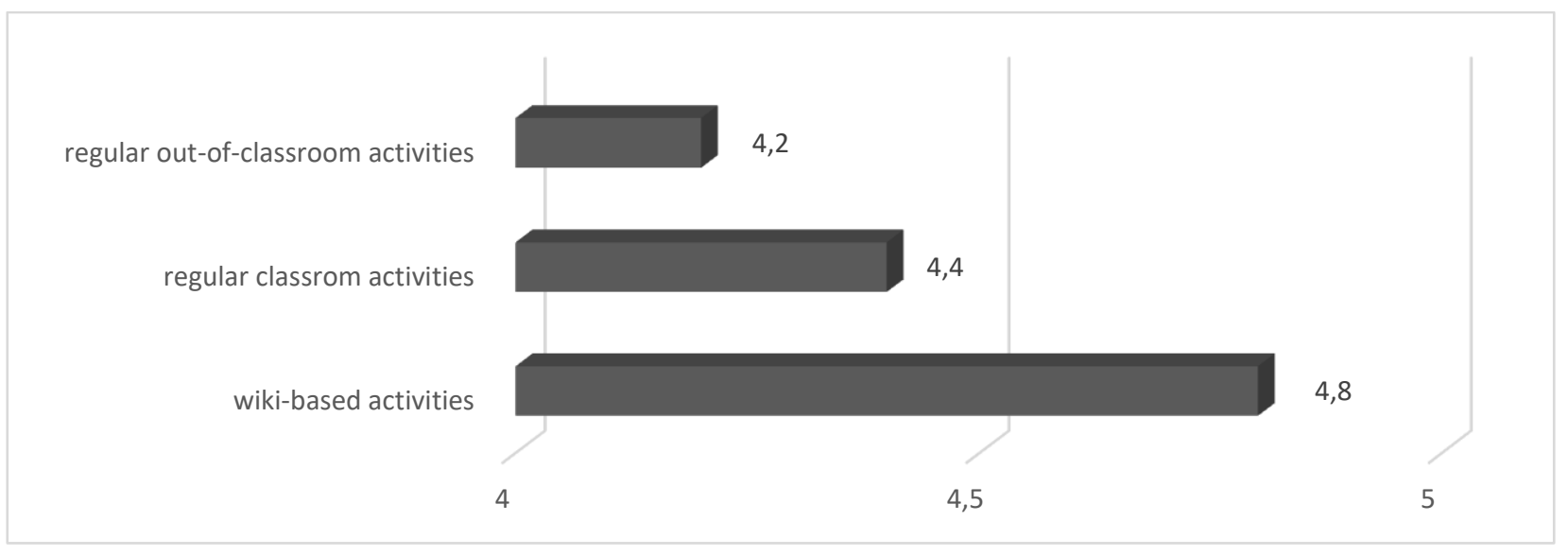

Figure 1. Comparative evaluation of activities

Table 1 presents the activities that received the highest ratings. The response scale was in the range from 1 (very poor) to 5 (very good). It can be concluded from the data presented in the Table 1 that the implemented wiki-based activities were accepted rather positively since the average ratings were in the range 4-4.5. It should also be outlined that about $30 \%$ of the offered activities are not presented in the Table 1 since they received an average rating in the range of 3.4-3.9, which was considered as not satisfactory enough. 
Table 1

Description of wiki-based tasks and the results of their evaluation

\begin{tabular}{|c|c|}
\hline Evaluation & Activity \\
\hline $\begin{array}{l}\text { Interesting: } 4.5 \\
\text { Rewarding: } 4,3 \\
\text { Challenging: } 4.4 \\
\text { Usable: } 4.2\end{array}$ & $\begin{array}{l}\text { Brainwriting - The goal is to create a list of possible solutions to an } \\
\text { offered problem. Students work in small groups. The first group } \\
\text { offers at least two solutions, provide explanations for their solutions, } \\
\text { add at least two new ideas or elaborate some of the ideas offered so } \\
\text { far. Then they forward these idea-set to the next group on the list, } \\
\text { which adds one or two additional solutions, then, forwards it to the } \\
\text { next group, and so on, until a list of solutions to the problem is } \\
\text { created. All the ideas are posted and lnked on a wiki-page. }\end{array}$ \\
\hline $\begin{array}{l}\text { Interesting: } 4.5 \\
\text { Rewarding: } 4.3 \\
\text { Challenging: } 4.1 \\
\text { Usable: } 4.2\end{array}$ & $\begin{array}{l}\text { Debate. Students work in into two or three opposing teams to } \\
\text { participate in a virtual discussion (debate) on a controversial topic. } \\
\text { Teams are to defend their position and attack the given proposition } \\
\text { respectively by presenting relevant arguments from referenced } \\
\text { sources. }\end{array}$ \\
\hline $\begin{array}{l}\text { Interesting: } 4.3 \\
\text { Rewarding: } 4.4 \\
\text { Challenging: } 4.1 \\
\text { Usable: } 4.2\end{array}$ & $\begin{array}{l}\text { Hotlist. The goal is to create a list of six web-based resources on a } \\
\text { given topic Students work in pairs or groups conducting a search on } \\
\text { the internet, analyzing different sources and choosing the most } \\
\text { relevant. The list should include the title of each web resource, its } \\
\text { URL, hyperlinks, a brief annotation describing the content and the } \\
\text { proving value of the particular resource, etc. }\end{array}$ \\
\hline $\begin{array}{l}\text { Interesting: } 4.3 \\
\text { Rewarding: } 4,4 \\
\text { Challenging: } 4.1 \\
\text { Usable: } 4.2\end{array}$ & $\begin{array}{l}\text { Chain writing. Students work in pairs or small groups. The aim is to } \\
\text { respond to an open question reviewing the course material or topic. } \\
\text { The first pair or small group receives a set of questions based on a } \\
\text { course or topic content and formed by their teacher, answer them } \\
\text { and makes a new set of relevant questions, than forwards it to the } \\
\text { next pair or group, and so on. The chain is posted on a wiki page so } \\
\text { all can have an access the review created. }\end{array}$ \\
\hline $\begin{array}{l}\text { Interesting: } 4.1 \\
\text { Rewarding: } 4.5 \\
\text { Challenging: } 4.2 \\
\text { Usable: } 4.3\end{array}$ & $\begin{array}{l}\text { Vocabulary set. Students work in pairs or small groups. The task is } \\
\text { to create a glossary for the proposed topic. Students should choose } \\
\text { the most relevant words and present them in a form of blocks. Every } \\
\text { block includes definition, translation, contextual examples and } \\
\text { comments and contains hyperlinks for further information on } \\
\text { demand. The glossary is posted on a wiki-page. }\end{array}$ \\
\hline
\end{tabular}

The analyses of the obtained results revealed that students appreciated the opportunity to acquire new learning experience and positively evaluated the use of wiki elements in our training process. Wikis have a great potential to compliment the training process engaging students in content across the curriculum and being timeand cost-saving option for a teacher to manage the calss. However, implementing wikis requires not only careful planning, but also regular monitoring the students' feedback. 


\section{References:}

1. Ebner, M., Kickmeier-Rust, M., \& Holzinger, A. (2008). Utilizing Wiki-Systems in higher education classes: a chance for universal access? Universal Access in the Information Society, 7, 199-207. Retrieved from https://tccl.arcc.albany.edu/knilt/images/c/c5/Fulltext.pdf.

2. Ruth, A., \& Houghton, L. (2009). The Wiki way of learning Australasian Journal of Educational Technology, 25(2), 135-152. Retrieved from https://ajet.org.au/index.php/AJET/article/ view/1147/395.

3. Wang, Y. (2014). Using wikis to facilitate interaction and collaboration among EFL learners: A social constructivist approach to language teaching. System, 42(1), 383-390. Retrieved from: https://www.sciencedirect.com/science/article/pii/S0346251X14000141?via\%3Dihub

4. Duffy, Peter D. \& Bruns, Axel (2006) The Use of Blogs, Wikis and RSS in Education: A Conversation of Possibilities. In Online Learning and Teaching Conference 2006, 26 Sep. 2006, Brisbane. Retrieved from: https://eprints.qut.edu.au/5398/.

5. Altanopoulou, P. and Tselios, N. (2017). Assessing Acceptance Toward Wiki Technology in the Context of Higher Education. The International Review of Research in Open and Distributed Learning, 18(6). Retrieved from: https://www.learntechlib.org/p/181981/

6. Cilliers, L. (2016). Wiki acceptance by university students to improve collaboration in higher education. Innovations in Education and Teaching International, 54(5), 485-493. Retrieved from: https://www.tandfonline.com/doi/full/10.1080/14703297.2016.1180255 